\title{
PERUBAHAN PENGETAHUAN IBU HAMIL TENTANG KEKURANGAN ENERGI KRONIK PASCA PENYULUHAN
}

\section{KNOWLEDGE CHANGE OF PREGNANT MOTHER ABOUT CHRONIC ENERGY DEFICIENCY POST COUNSELING}

\author{
Roekmy Prabarini Ario \\ Akademi Kebidanan Ibrahimy Sukorejo Situbondo \\ Email: roekmyprabariniario@gmail.com
}

\begin{abstract}
ABSTRAK
Kekurangan Energi Kronik (KEK) adalah kekurangan asupan energi dan protein pada Ibu hamil yang berlangsung secara terus menerus dan mengakibatkan timbulnya gangguan kesehatan. Adapun tujuan dari penelitian ini adalah untuk mendapatkan Perubahan Pengetahuan Ibu Hamil Tentang KEK (Kekurangan Energi Kronik) Pasca Mendapat Penyuluhan di Wilayah Puskesmas Situbondo. Metode pada penelitian ini metode praeksperimen (Preeksperimen) dengan rancangan one group pretest- postetest design'. Tehnik sampling penelitian adalah proportionate starfied simple randem dengan jumlah populasi keseluruhan 42 ibu hamil. Data yang diperoleh diolah dengan Editing, Coding, dan Tabulasi. Instrumen yang digunakan pada penelitian ini adalah kuisioner. Dari hasil analisa data diketahui bahwa perubahan pengetahuan ibu hamil sebelum mendapat penyuluhan adalah $2(4,76 \%)$ ibu hamil yang pengetahuan baik sedangakan setelah mendapat penyuluhan $38(90,4 \%)$ ibu hamil yang pengetahuan baik.Dari hasil penelitian ini dapat disimpulkan bahwa adanya perubahan pengetahuan ibu hamil tentang KEK pasca mendapat penyuluhan di Wilayah Puskesmas Situbondo
\end{abstract}

Kata kunci : Pengetahuan, Penyuluhan, Kekurangan Energi Kronik

\begin{abstract}
Chronic Energy Deficiency is a deficiency of energy and protein intake in pregnant women that lasted continuously and resulted in the occurrence of health problems. The purpose of this research was to get the Change of Knowledge of Pregnant Women About Chronic Energy Deficiency After Get the Counseling in Situbondo Health Center Area. The method in this research used pre experimental method (Preeksperimen) with one group pretest-postetest design. Research sampling technique used proportionate stratified random sampling with total population of 42 pregnant women. The data obtained is processed by Editing, Coding, and Tabulation. The instrument used in this study is a questionnaire. From the data analysis, it was known that the change of knowledge of pregnant mother before getting counseling is $2(4,76 \%)$ pregnant woman with good knowledge while after getting counseling $38(90,4 \%)$ pregnant mother with good knowledge. From result of this research can be concluded that The change of knowledge of pregnant women about chronic energy deficiency after getting counseling in Situbondo Health Care Area.
\end{abstract}

Keywords : Knowledge, Counseling, Chronic Energy Deficiency.

PENDAHULUAN

Gizi merupakan suatu proses penggunaan makanan yang dikonsumsi secara normal oleh suatu organisme melalui proses digestri, absorbsi, transportasi, penyimpanan, metabolisme dan pengeluaran zat-zat yang tidak digunakan untuk mempertahankan kehidupan, pertumbuhan dan fungsi normal dari organ-organ serta 
menghasilkan energi. Gizi pada wanita hamil adalah status gizi ibu yang optimal sehingga ibu mengalami kehamilan dengan aman, melahirkan bayi dengan potensi fisik dan mental yang baik (Asfiah, 2009).

Empat masalah gizi utama di Indonesia adalah Kekurangan Energi Kronis (KEK) Gangguan Akibat Kekurangan Yodium (GAKY), Kekurangan Vit A (KVA) dan anemia gizi besi. Sasaran program adalah remaja dan ibu hamil. Masalah yang banyak terjadi pada remaja dan ibu hamil adalah anemia, defisiensi besi, dan kelebihan atau kekurangan berat badan (Sulistyoningsih, 2011).

Berdasarkan Data Survey Demografi dan Kesehatan Indonesia (SDKI) 2012, angka kematian ibu melahirkan mengalami kenaikan dari 228 per 100.000 kelahiran hidup pada tahun 2007 menjadi 359 per 100.000 kelahiran hidup pada tahun 2012. Sehingga perlu upaya lebih keras guna mencapai target MDGs pada tahun 2015, yaitu AKI sebesar 102 per 100.00 kelahiran hidup. Hal ini dikarenakan faktor penyebab baik secara langsung maupun tidak langsung. Faktor penyebab langsung kematian ibu yakni perdarahan dan infeksi perdarahan menempati persentase tertinggi penyebab kematian ibu yaitu $28 \%$ yang disebabkan oleh anemia dan KEK.

Berdasarkan Riskesdas (2013) terjadi peningkatan proporsi ibu hamil dengan KEK dari $31,3 \%$ pada tahun 2010 menjadi 38,5\% pada tahun 2013. Peningkatan serupa juga terjadi pada WUS usia 15-19 tahun yang tidak hamil yaitu 30,9\% pada tahun 2010 menjadi $46,6 \%$.

Data dari Dinas Kesehatan Situbondo tahun 2013 menyebutkan bahwa jumlah ibu hamil yang mengalami KEK terdapat 943 ibu hamil KEK dari 8143 ibu hamil sedangkan pada tahun 2014 terdapat 922 ibu KEK dari 9046 ibu hamil.

Menurut data di Puskesmas pada tahun 2012-2014 jumlah ibu hamil yang mengalami KEK 39 orang di wilayah Puskesmas Situbondo, berikut tabel dari jumlah keseluruhan ibu hamil KEK.

Berdasarkan informasi dari progremer gizi Puskesmas Situbondo 3 tahun berturut-turut ternyata ibu hamil yang mengalami KEK yang paling banyak pada tahun 2014 dari keseluruhan ibu hamil yang ada, $28 \mathrm{ibu}$ hamil yang mengalami KEK. Dari uraian di atas dapat disimpulkan bahwa pada tahun 2014 jumlah ibu hamil yamg 
mengalami KEK naik secara cepat dibandingkan dengan tahun $2013 \mathrm{ibu}$ hamil yang KEK sebanyak 5 dan 2012 sebanyak 7 ibu hamil. Secara langsung kurang gizi dipengaruhi oleh ketidakcukupan makanan yang seimbang dan penyakit infeksi, secara tidak langsung dipengaruhi oleh ketersediaan pangan yang tidak cukup, pelayanan kesehatan dasar yang tidak memadai dan lebih lanjut masalah gizi disebabkan oleh kemiskinan, pendidikan rendah dan kesempatan kerja.

Kekurangan Energi Kronis pada saat kehamilan dapat berakibat pada ibu maupun pada janin yang dikandungnya. Pengaruh Kekuurangan Energi Kronik pada ibu hamil yaitu terjadi KKP (Kurang Kalori Protein), anemia, produksi ASI berkurang, sedangkan pada saat persalinan dapat mengakibatkan persalinan sulit dan lama, persalinan sebelum waktunya (Premature), perdarahan. Terhadap janin antara lain menimbulkan keguguran/ abortus, bayi lahir mati, kematian neonatal, cacat bawaan, anemia pada bayi dengan berat badan lahir rendah (BBLR) (Purwitasari, 2009)

Dalam menaggulangi masalah dan mencegah dampak dari Kekurangan Energi Kronik yaitu mengusahakan agar ibu hamil memeriksakan kehamilan secara rutin sejak hamil muda untuk mendeteksi secara dini kejadian Kekurangan Energi Kronik dan penyuluhan tentang asupan nutrisi yang dibutuhkan ibu hamil dan selalu menganjurkan ibu hamil minum $\mathrm{Fe}$ dan selalu diberikan makanan tambahan 3 bulan sekali untuk menaggulangi KEK ( Kekurangan Energi Kronik) pada ibu hamil.

Berdasarkan latar belakang tersebut maka perlu dilakukan penelitian tentang "Pengaruh penyuluhan Terhadap Tingkat Pengetahuan Ibu Hamil Tentang KEK di Puskesmas Situbondo Tahun 2015.

\section{METODE PENELITI}

Jenis penelitian yang akan digunakan rancang adalah pra eksperimen (Preeksperimen) dengan rancangan one group pretest-posttest design. Penelitian ini dilakukan di Wilayah Puskesmas Situbondo Penelitian ini dilakukan di Wilayah Puskesmas Situbondo. Populasi dalam penelitian ini yaitu semua ibu hamil yang ada di wilayah Puskesmas Situbondo sebanyak 275 ibu hamil. Peneliti mengambil $15 \%$ dari jumlah populasi. Jadi sampel dalam penelitian ini terdapat $42 \mathrm{ibu}$ hamil. 


\section{HASIL DAN PEMBAHASAN}

Berdasarkan hasil uji statistik didapatkan hasil sebagaimana didalam tabel:

Tabel 1 Distribusi Frekuensi Berdasarkan Umur Responden di Wilayah Puskesmas Situbondo

\begin{tabular}{cccc}
\hline No & Umur & Frekuensi & Persentase \\
\hline 1 & $21-25$ & 12 & 28,6 \\
2 & $26-30$ & 15 & 35,7 \\
3 & $31-35$ & 8 & 19,0 \\
4 & $36-40$ & 7 & 16,7 \\
& Total & 42 & 100 \\
\hline
\end{tabular}

Berdasarkan tabel 1 hampir setengahnya responden yaitu 15 responden $(35,7 \%)$ berumur $26-30$ dan sebagian kecil yaitu 7 responden $(16,7 \%)$ berumur $36-40$.

Tabel 2 Distribusi Frekuensi Berdasarakan Pendidikan di Wilayah Puskesmas Situbondo

\begin{tabular}{cccc}
\hline No & Pendidikan & Frekuensi & Persentase \\
\hline 1 & SMA & 25 & 59,5 \\
2 & SMP & 12 & 28,5 \\
3 & SD & 5 & 12,0 \\
& Total & 42 & 100 \\
\hline
\end{tabular}

Berdasarkan tabel 2 sebagian besar responden yaitu 25 responden $(59,5 \%)$ berpendidikan SMA dan sebagian kecil yaitu 5 responden $(12,0$ $\%)$ berpendidikan SD.
Tabel 3 Distribusi Frekuensi Berdasarkan Daerah Asal Responden di Wilayah Puskesmas Situbondo

\begin{tabular}{cccc}
\hline No & Daerah Asal & Frekuensi & Persentase \\
\hline 1 & Patokan & 7 & $16,6 \%$ \\
2 & Kotakan & 9 & $21,4 \%$ \\
3 & Tenggir & 5 & $11,9 \%$ \\
4 & Dawhan & 6 & $14,3 \%$ \\
5 & Banyuglugur & 5 & $11,9 \%$ \\
6 & Olean & 10 & $23,9 \%$ \\
& Total & 42 & 100 \\
\hline
\end{tabular}

Berdasarkan tabel 3 sebagian kecil responden berasal dari Olean dengan jumlah 10 orang $(23,9 \%)$

Tabel 4 Distribusi Frekuensi Berdasarkan Perolehan Informasi Responden di Wilayah Puskesmas Situbondo

\begin{tabular}{cccc}
\hline No & $\begin{array}{c}\text { Perolehan } \\
\text { Informasi }\end{array}$ & Frekuensi & Persentase \\
\hline 1 & Ya & 15 & 35,8 \\
2 & Tidak & 27 & 64,2 \\
& Total & $\mathbf{4 2}$ & $\mathbf{1 0 0}$ \\
\hline
\end{tabular}

Berdasarkan tabel 4 sebagian

besar responden yaitu 27 responden $(64,2 \%)$ tidak pernah mendapat informasi dan hampir setengahnya yaitu sebanyak 15 responden $(35,8 \%)$ pernah mendapat informasi. 
Tabel 5 Distribusi Frekuensi Berdasarkan Sumber Informasi Responden di Wilayah Puskesmas Situbondo

\begin{tabular}{|c|c|c|c|}
\hline No & $\begin{array}{l}\text { Perolehan } \\
\text { Informasi }\end{array}$ & Frekuensi & $\begin{array}{c}\text { Persenta } \\
\text { se }\end{array}$ \\
\hline 1 & $\begin{array}{l}\text { Tenaga } \\
\text { Kesehatan }\end{array}$ & 10 & 66,7 \\
\hline 2 & Koran/ Majalah & 1 & 6,7 \\
\hline 3 & Radio/ TV & 2 & 13,3 \\
\hline 4 & Lain-lain & 2 & 13,3 \\
\hline & Total & 15 & 100 \\
\hline
\end{tabular}

Berdasarkan tabel 5 sebagian besar responden yaitu 10 responden $(66,7 \%)$ memiliki sumber informasi dari tenaga kesehatan dan sebagian kecil yaitu 2 responden $(13,3 \%)$ memiliki sumber informasi dari media, TV, dan radio.

Tabel 6 Distribusi Frekuensi Berdasarkan Pengalaman Keluarga Responden di Wilayah Puskesmas Situbondo

\begin{tabular}{|c|c|c|c|}
\hline No & $\begin{array}{c}\text { Pengalaman } \\
\text { Keluarga }\end{array}$ & Frekuensi & Persentase \\
\hline 1 & $\mathrm{Ya}$ & 15 & 35,8 \\
\hline 2 & Tidak & 27 & 64,2 \\
\hline 3 & Total & 42 & 100 \\
\hline
\end{tabular}

besar responden yaitu 27 responden $(64,2 \%)$ tidak ada pengalaman keluarga dan hampir setengahnya 15 responden yaitu $(35,8 \%)$ memiliki pengalaman keluarga.
Tabel 7 Distribusi Frekuensi Pengetahuan Responden Tentang KEK (Kekurangan Energi Kronik) Sebelum Penyuluhan di Wilayah Puskesmas Situbondo.

\begin{tabular}{|c|c|c|c|}
\hline No & Pengetahuan & Frekuensi & Persentase \\
\hline 1 & Baik & 2 & 4,8 \\
\hline 2 & Cukup & 8 & 19,0 \\
\hline \multirow[t]{2}{*}{3} & Kurang & 32 & 76,2 \\
\hline & Total & 42 & 100 \\
\hline
\end{tabular}
seluruhnya yaitu 32 responden $(76,1 \%)$ memiliki pengetahuan kurang dan sebagian kecil yaitu 8 responden $(19,1 \%)$ memiliki pengetahuan baik.

Tabel 8 Distribusi Frekuensi Pengetahuan Responden Tentang KEK (Kekurangan Energi Kronik) Sesudah Penyuluhan di Wilayah Puskesmas Situbondo

\begin{tabular}{|c|c|c|c|}
\hline No & Pengetahuan & Frekuensi & Persentase \\
\hline 1 & Baik & 38 & 90,5 \\
\hline 2 & Cukup & 3 & 7,2 \\
\hline 3 & Kurang & 1 & 2,3 \\
\hline & Total & 42 & 100 \\
\hline
\end{tabular}
seluruhnya responden yaitu 38 responden( 90,5\%) mempunyai pengetahuan baik dan sebagian kecil responden yaitu 1 responden $(2,3 \%)$ memiliki pengetahuan kurang. 
Tabel 9 Distribusi Pengetahuan Responden Tentang Kekurangan Energi Kronik Sebelum dan Sesudah Penyuluhan

\begin{tabular}{cccccc}
\hline & & \multicolumn{3}{c}{ Pengetahuan } \\
No & Kriteria & \multicolumn{2}{c}{ Sebelum } & \multicolumn{2}{c}{ Sesudah } \\
& & F & \% & F & \% \\
\hline 1 & Baik & 2 & 4,8 & 38 & 90,5 \\
2 & Cukup & 8 & 19,0 & 3 & 7,2 \\
3 & Kurang & 32 & 76,2 & 1 & 2,3 \\
& Total & $\mathbf{4 2}$ & $\mathbf{1 0 0}$ & $\mathbf{4 2}$ & $\mathbf{1 0 0}$ \\
\hline
\end{tabular}

Berdasarkan tabel 9 diperoleh hampir seluruhnya yaitu 32 responden (76,2\%) memiliki pengetahuan kurang. Selanjutnya setelah diberikan penyuluhan maka terjadi penurunan tingkat pengetahuan responden yang kurang yaitu hanya 1 responden $(2,3 \%)$.

Dari hasil penghitungan data penelitian dengan menggunakan uji “Wilcoxon Match Pairs Test” dengan perhitungan dengan menggunakan software SPSS 16 pada tingkat kemaksimalan $(\alpha=0,05)$ diperolehkan hasil nilai $Z_{\text {hitung }}$ sebesar -5695 dan nilai $\mathrm{Z}_{\text {tabel }}$ sebesar $-1,96$ sehingga $\mathrm{H}_{1}$ ditolak yang artinya ada pengaruh yang signifikan dari intervensi penyuluhan terhadap pengetahuan ibu hamil di Wilayah Kota Situbondo.

Menurut teori Mubarak (2011) membuktikan bahwa antara teori dan fakta yang ada dilapangan sesuai yaitu semakin tinggi pendidikan seseorang maka pengetahuan sesorang samakin baik semakin dan mudah pula mereka menerima informasi, dan pada akhirnya pengetahuan yang dimilikinya akan semakin banyak. Serta cara berfikir seseorang yang pendidikannya lebih tinggi akan lebih meluas dibandingkan dengan yang berpendidikan rendah.

Menurut Mahfodz

(2009)

bimbingan dan penyuluhan merupakan kontak antara klien dengan petugas lebih intensif. Setiap masalah yang dihadapi oleh nklien dapat dikorek dan dibantu penyelesainnya. Akhirnya klien tersebut akan dengan sukarela dan berdasarkan kesadaran penuh perhatian, akan menerima perilaku tersebut. Dalam proses penyuluhan bisa menggunakan wawancara yang dimana wawancara tersebut merupakan wawancara antara petugas kesehatan dengan klien untuk menggali informasi. Keterbatasan informasi juga mempengaruhi tingkat pengetahuan seseorang karena informasi akan memberikan pengaruh pada pengetahuan seseorang. Meskipun seseorang memiliki pendidikan yang rendah tetapi jika dia mendapat informasi yang baik dari berbagai sumber misalnya koran, televisi, ataupun dari orang-orang terdekat akan meningkatkan pengetahuan seseorang. 
Dari data yang telah diuraikan menyatakan bahwa pengetahuan sebelum penyuluhan sebagian kecil baik yaitu 2 responden $(4,76 \%)$ dan hampir seluruhnya berpengetahuan kurang yaitu 32 responden $(76,2 \%)$ dan sesudah diberikan penyuluhan terdapat 38 responden $(90,5 \%)$ berpengetahuan baik dan sebagian kecil berpengetahuan kurang yaitu 1 responden (2,3\%), dan dari uraian diatas yaitu adanya peningkatan pengetahuan responden sebelum dan sesudah penyuluhan sebesar $85,74 \%$ dari yang mempunyai pengetahuan baik, dan terjadi penurunan jumlah responden yang memiliki pengetahuan kurang yaitu sebesar $73,9 \%$. Perubahan pengetahuan yang signifikan dari sebelum dan sesudah penyuluhan disebabkan karena beberapa factor yang bisa mempengaruhi pengetahuan antara lain kurangnya informasi dari media massa dan pendidikan yang rendah.

Sementara itu hasil uji statistik diperoleh hasil nilai $Z_{\text {hitung }}$ sebesar -5,695 dan nilai $\mathrm{Z}_{\text {tabel }}$ sebesar -1,96 sehingga $\mathrm{H}_{1}$ diterima yang artinya ada pengaruh yang signifikan dari intervensi penyuluhan terhadap pengetahuan ibu hamil di Wilayah Puskesmas Situbondo.

\section{SIMPULAN DAN SARAN}

Dengan memperhatikan hasil penelitian dan pembahasan dapat disimpulkan bahwa Adanya perubahan pengetahuan ibu hamil setelahah dilakukan penyuluhan semakin baik dibandingkan sebelum diberikan penyuluhan, Hasil analisis pengetahuan sebelum dan sesudah penyuluhan dengan menggunakan uji "Wilcoxon Match Pairs Test" diperolehkan hasil nilai Zhitung sebesar -5695 dan nilai Ztabel sebesar -1,96 sehingga $\mathrm{H}_{1}$ diterima yang artinya ada pengaruh penyuluhan terhadap pengetahuan ibu hamil di Wilayah Puskesmas Situbondo

Diharapkan pada saat melakukan penelitian waktu yang diberikan cukup panjang, agar penelitian dilakukan lebih maksimal dan hasil yang didapatkan lebih memuaskan, dan bagi mahasiswi yang melakukan penelitian didaerah yang lebih jauh dijangkau bisa melakukan penelitian dengan sangatsamgat maksimal.

\section{DAFTAR PUSTAKA}

Arisman. 2007. Gizi Daur Kehidupan. Jakarta: ECG

Asfuah. 2009 . Gizi Untuk Kebidanan. Yogyakarta : Nuhamedika

Dewi, V. N. 2013. Asuhan Neonatus Arikunto. S. 2006. Produser 
Penelitian Suatu Pendapatan Praktik. Jakarta: Rineka Cipta

S. 2010. Produser Penelitian Suatu Pendapatan Praktik. Jakarta: Rineka Cipta

Dewi. 2011. Manajemen Perbaikan Gizi Masyarakat . Surabaya: CV. Duta Putri Airlangga

Hidayat. A. A. 2007. Metode Penelitian Teknik Analisa Data . Jakarta: Salemba Medika

Machfoedz, I 2009 . Pendidikan Kesehatan Bagian Dari Promosi Kesehatan. Yogyakarta :Fitramaya

Notoadmojo . 2010. Metode Penelitian Kesehatan.. Jakarta : Rineka Cipta
2011. Kesehatan Masyarakat. Jakarta : Rineka Cipta
2012. Metodologi Penelitian Kesehatan. Jakarta: PT Rineka Cipta
Purwitasari,2009 Gizi Untuk Kesehatan. Jakarta: Rineka

Riskesdas. 2013 Riset Kesehatan Dasar

SDKI. 2012 Data Survey Demografi dan Kesehatan Indonesia

Sulistiyoningsih. 2011 Gizi Untuk Kebidanan: Yogyakarta: Nuhamedika

Wijono. 2009. Manajemen Perbaikan Gizi Masyarakat . Surabaya: CV. Duta Putri Airlangga 